\title{
Death and Taxes: the Case of the Depletion of Pearl Oyster Beds in Sixteenth-Century Venezuela
}

\author{
ALDEMARO ROMERO \\ Environmental Studies Program and Department of Biology, Macalester College, 1600 Grand Avenue, St. Paul, MN \\ 55105-1899, U.S.A.
}

\begin{abstract}
Interdisciplinary approaches have been used not only to interpret past patterns of natural resource utilization but also to provide useful tools for conservation biology and resource management. I report bere the depletion of the pearl oyster (Pinctada imbricata) beds off the coast of Cubagua, Venezuela, in the sixteenth century and the replacement of the oyster by the turkey-wing mussel (Arca zebra). I used bistorical tax data to conclude that the rapid depletion of this resource was the result not only of overexploitation in a short period of time but also of the ecology of the place used by humans to carry out such activity. Under conditions of ecological stress generated by overexpoloitation, the turkey-wing mussel outcompeted the pearl oyster, thus preventing its recovery. Finally, I propose that the exploitation of the pearl oyster beds directly influenced the demographic, social, and cultural conditions of the indigenous buman populations in the Caribbean and, to a certain extent, in Africa.
\end{abstract}

Muerte e Impuestos: El Caso del Agotamiento de los Bancos de Ostras Perliferas en Venezuela en el Siglo XVI

Resumen: Se ban utilizado enfoques interdisciplinarios no solo para interpretar patrones bistóricos de uso de recursos naturales, sino también para proporcionar berramientas útiles a la biología de la conservación y el manejo de recursos. Aquí reporto el agotamiento de los bancos de ostras perliferas (Pinctada imbricata) en la costa de Cubagua, Venezuela, en el siglo XVI y el reemplazo de esta ostra por el mejillón (Arca zebra). Utilicé datos bistóricos de impuestos para concluir que el rápido agotamiento de este recurso fue resultado no sólo de la sobreexplotación en un corto período de tiempo sino también de la ecología del sitio utilizado por bumanos para llevar a cabo tal actividad. Bajo condiciones de estrés ecológico generados por la sobre explotación, el mejillón desplazó competitivamente a la ostra, evitando así su recuperación. Finalmente, propongo que la explotación de los bancos de ostras perliferas influyó directamente sobre las condiciones demográficas, sociales y culturales de las poblaciones bumanas indígenas en el Caribe y, hasta cierto punto, en África.

\section{Introduction}

There has been increasing interest in approaching conservation biology from a historical perspective, which implies an interdisciplinary approach (Meine 1999). Jackson (2001:5411) has said that "Paleoecological, archaeological, and historical data are the only means for extending ecological records back long enough to docu-

Current address: Department of Biological Sciences, Arkansas State University, P.O. Box 599, State University, AR 72467, U.S.A., email aromero@astate.edu

Paper submitted August 20, 2001; revised manuscript accepted October 21, 2002. ment . . the magnitude of earlier anthropogenic change." Past approaches have centered on population abundance and species extinction when humans occupy new areas (e.g., Simmons 1993; Coates 1998). Overexploitation (the "overkill" model; Martin 1973, 1990) and habitat modification (Agenbroad et al. 1990 and papers therein) resulted in species extinctions (termed neoextinctions or Holocene, historical, contemporary, or present-day extinctions; Carlton 1993) as humans moved from one continent to another. For the American continent this phenomenon took place in the last 10,000-15,000 years. Yet the exact mechanisms by which those extinctions occurred are not well under- 
stood (Webster \& Webster 1984; Forester \& Machlis 1996; Pimm 1996).

Because most neoextinctions can be attributed directly or indirectly to humans, the study of the interactions between the environment and human social organization and behavior can help us better understand the mechanisms leading to these types of extinctions. This understanding, in turn, may be used to establish more effective conservation policies, particularly in developing nations, where there are still large human populations living in rural areas or still practicing semi-indigenous modes of living. This interdisciplinary approach has al ready been used to reject the hypothesis of the "ecologically noble savage” (e.g., Alvard 1995; Kallendorf 1995; Buege 1996; Headland 1997) and to incorporate an environmental perspective into historical interpretations (e.g., Ponting 1991; Sale 1991; Pastor Bodmer 1992; Simon 1997; Diamond 1998; Martin \& Szuter 1999). Most neoextinction studies have dealt with terrestrial ecosystems and species, but recently some authors have started to focus on this phenomenon in coastal ecosystems (e.g., Jackson 2001).

Despite progress in understanding ecological issues from a historical perspective (e.g., Crumley 1994; Balee 1998; McCann 1999a,b; Egan \& Howell 2001), some questions remain. One involves the impact of humans who arrive in environments inhabited by other humans with very different economic and social structures.

The arrival of Europeans on the American continent offers a clear opportunity to analyze neoextinctions. Post-Columbian extinctions are not only relatively recent but also much better documented than prehistoric ones, which provides an opportunity to better understand the interplay of social and ecological factors. I describe what I believe was the first case of depletion of a natural resource by Europeans on the American continent: the demise of pearl oyster (Pinctada imbricata) beds around the island of Cubagua off the coast of Venezuela.

Before Columbus's arrival on the American continent, pearls were used as ornaments among indigenous peoples of the southern Caribbean. By the time of Columbus's first voyage to America in 1492, pearls were already considered an important commodity in trade between Europe and what was known then as the Indies (de Silva 1978; Bernabeu 1995). Trade records, paintings, and engravings of the fifteenth and sixteenth centuries show that pearls were in great demand and were used in abundance by people of rank and fortune (Kunz \& Stevenson 1908). Pearls were among the most valuable commodities that Spanish ships carried to Europe (Mosk 1938; Haring 1964).

Until 1530 the value of pearls shipped from America to Europe averaged more than one-third of all the yearly production of the gold and silver mines on the American continent. Before the establishment of Mexican and Pe- ruvian mines, pearl exports from the New World under Spanish control exceeded the value of all other exports combined (Kunz \& Stevenson 1908). I characterize the historical, economic, social, and political circumstances that led to the depletion of the pearl oyster beds of $\mathrm{Cu}$ bagua and establish the connections between those factors and the natural history of the resource that was depleted. I use this information to make a case that the pearl harvest was an unsustainable use of a resource that lead to its rapid local depletion and that had important impacts on native peoples.

\section{Geographical Background}

Coche, Cubagua, and Margarita are three major islands off the eastern coast of Venezuela. They are grouped politically as part of the state of Nueva Esparta and are located about 10,17 , and $25 \mathrm{~km}$, respectively, from the Araya Peninsula on the mainland of Venezuela. The island of Cubagua is $9 \mathrm{~km}$ south of the coast of Margarita (Willis 1976) (Fig. 1).

Cubagua is an island of subeliptic shape with a total area of $22 \mathrm{~km}^{2}$ of mostly flat landscape and a coastline lined with cliffs (Kugler 1957; Anonymous 1970). The exception in this general landscape is the northeast corner of the island, where there is a rectangular-shaped lowland known as La Cabecera de Cubagua (Fig. 2). The events that led to the extinction took place in this lowland in the town of Nueva Cádiz.

Cubagua is, ecologically speaking, a dry desert with an annual precipitation of $250 \mathrm{~mm}$. The island is well drained due to the sandy and clay soil over mostly lime-

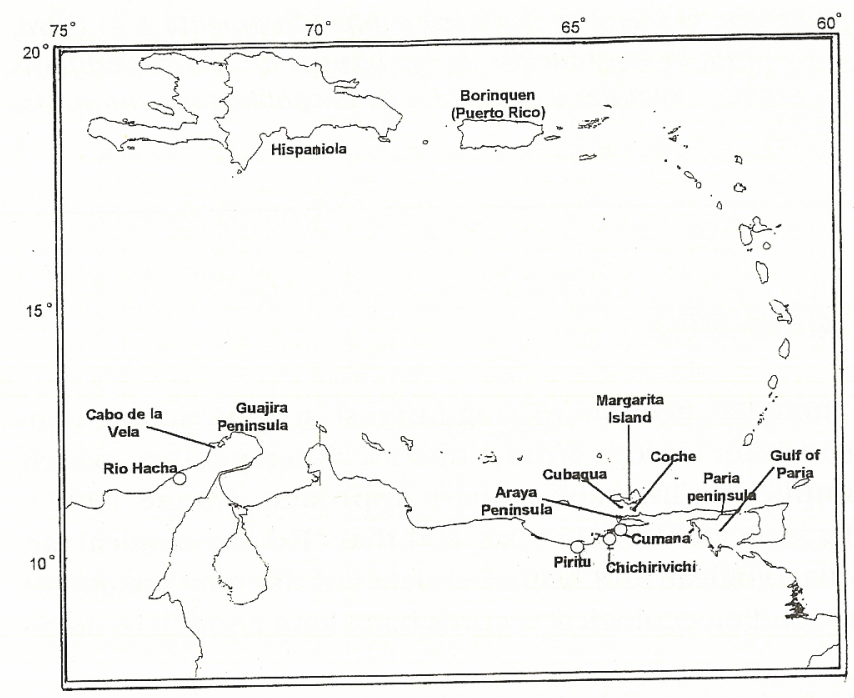

Figure 1. Map of the area in which the exploitation of the pearl oyster beds and related bistorical events in the Caribbean took place. 
$11.2^{\circ 64.4^{\circ}}$

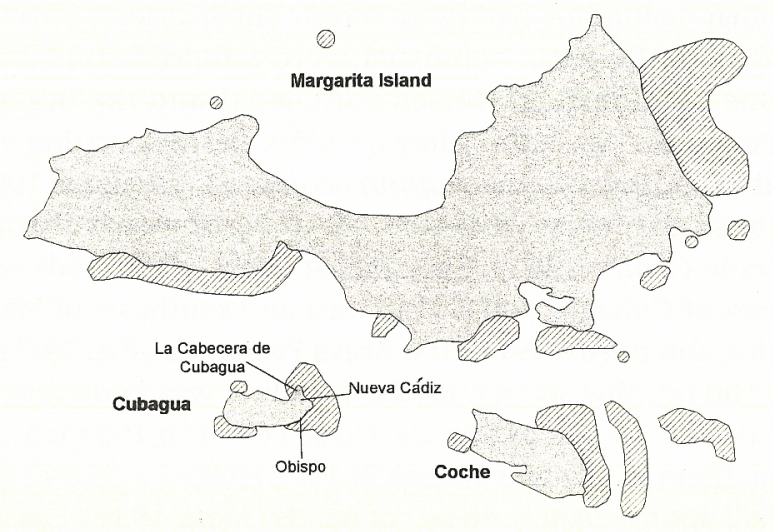

$10.7^{\circ}$

\section{Pearl oyster beds}

$20 \mathrm{~K}$

Figure 2. Map of the islands of Margarita, Coche, and Cubagua. Shaded areas represent former or current pearl oyster beds (after Salaya \& Salazar 1972).

stone bedrock (Helmer 1962). The island's only fresh water occurs in small, underground reservoirs. All plant species are sparse and typically xerophytic (Johnston 1909; Olivo Chacín 1989).

\section{Methods}

To reconstruct the circumstances under which the pearl oyster beds became depleted, I synthesized historical, economic, political, social, and biological information related to the pearl oyster and its exploitation. For the historical narrative I relied on historic accounts (e.g., de Las Casas 1552/1992; López de Gómara 1554/1965; de Castellanos 1589/1857), modern studies of earlier documents (e.g., Morón 1954; Otte 1961; Helmer 1962), and archaeological findings on the islands (summarized by Willis 1976).

To understand the impact of exploitation on the population ecology of the Cubagua pearl oyster beds, I calculated the number of individual oysters taken, based on a summary of tax records (Otte 1977). To ensure that my calculations were made in the most conservative manner, I developed the following protocol:

(1) I only used data from 1515 on, the year in which precise tax records began to be kept, despite the fact that significant exploitation had taken place in previous years.

(2) I ignored pearls that were not declared to the tax authorities. Historic and contemporary estimates show that more than half the pearls extracted were not declared, in order to evade taxes, or were used as local currency (Benzoni 1565; Otte 1977).

(3) I ignored decimals and rounded numbers up to the nearest low integer.

(4) Because official figures from 1509 on represented a $20 \%$ tax of the production, I multiplied these figures by five to obtain the gross production.

(5) To generate the most conservative estimates of oysters collected per pearls produced, I assumed the highest estimates of pearl productivity or yield per number of oysters collected in Cubaguan waters between 1515 and 1541 .

(6) Given that the Spanish records primarily contained information about the weight and quantity of the pearls rather than their quality, I assumed that all pearls were of the highest quality and weight (five carats). In that way assumptions about the number of pearls produced were maximized per unit of effort. Thus, to apply the most conservative approach, I assumed the highest possible productivity and the lowest number of oysters extracted per pearl.

\section{History}

\section{Pre-Columbian Period}

The earliest inhabitants of the Caribbean basin were the Paleo-Indians who arrived on Cubagua about 4325 B.P. ( 2325 B.C.) \pm 80 years. They traveled from the mainland to the islands by means of rafts and were subsistence fishers (Rouse \& Cruxent 1963; Cooke 1998). On the mainland they collected and gathered food and hunted big game but did not practice agriculture or use stone tools. These peoples probably migrated in response to the extinction of the large game animals and the decline of the big game-hunting culture on the mainland (Watts 1987). In the Caribbean, Paleo-Indians were followed by Meso-Indians (about 3000 B.P.), who also visited Cubagua. Meso-Indians were more technologically sophisticated and reached the Greater Antilles from what is today Venezuela by using their navigational skills. They also lacked agricultural skills and were mostly collectors and fishers. Only a few Meso-Indians remained by the time Europeans arrived: a small group in western Cuba, the Guanahacabibe (wrongfully called ciboney), and another unnamed group in the southwestern peninsula of Hispaniola (Watts 1987).

Throughout the Caribbean, Meso-Indians were supplanted by the Neo-Indians. The Neo-Indians were composed of two distinct groups: the Arawaks and the Caribs. The Arawaks originated in South America. They started colonizing the Greater Antilles beginning about 2100 B.P., and they visited Cubagua (Rouse \& Cruxent 
1963). They were the first Amerindians encountered by Columbus. Arawaks were mostly farmers who sometimes lived in stable villages. They also consumed fish, shellfish, turtles, and manatees (Rouse 1964). Land animals played a minor role in their diet (Watts 1987).

The Caribs came from the Orinoco region, and they came after the Arawaks. They colonized the Lesser Antilles about 1000 B.P. By the time of Columbus, the Caribs were living in what are today northern Brazil, the Guianas, Venezuela, and the Lesser Antilles. The Arawaks dominated the islands north of Venezuela (including Margarita, north to Cubagua), Trinidad, and the Greater Antilles. Like other cultures before them, the Arawaks visited Cubagua but never established permanent settlements there (Rouse \& Cruxent 1963). The Caribs, also practiced agriculture, as did the Arawaks, but because they were aggressive expansionists and thus tended to move more, they depended more than the Arawaks in their hunting, fishing, and collecting. The Arawaks feared the Caribs as warlike groups who, during certain periods, raided Arawak settlements for slaves and sometimes practiced cannibalism. Spaniards involved in the pearl oyster fishing in Cubagua exploited this fear of the Caribs. It is difficult to determine the population size of all indigenous people and thus their potential effect on natural resources. Past attempts to estimate population size have been controversial (for a summary and analysis of these controversies, see Henige 1998). An accepted figure for the number of humans inhabiting the area considered for this study at the time of Columbus's arrival is 50,000 (Lockhart \& Schwartz 1983).

The most likely reason that none of these native peoples settled permanently in Cubagua was the lack of fresh water. Because none of these cultures had a written language, we know they used oysters for food and pearls for ornamentation only through the accounts of the Spaniards (Willey 1971; Willis 1976).

\section{Discovery and First European Exploitations (1498-1502)}

Christopher Columbus was the first European to realize the economic potential of Cubagua. During his third voyage in 1498, he obtained more than six marks (about $1.4 \mathrm{~kg}$ ) of pearls by trading hawk bells (small brass bells used to decorate bustles, dance sticks, bonnets, and bags), beads, and sugar for them with the Arawaks of the Paria Peninsula, on the eastern continental coast of what is today Venezuela (Fig. 1). Arawaks boarded Columbus's ship and, while trading the pearls they wore, told him where the pearl oyster beds were. Because of spoiling cargo and his deteriorating health, however, he elected to continue to his final destination. He never returned to those waters (Sauer 1966).

Columbus's political enemies in Spain took advantage of the fact that he never set foot on the Paria Peninsula, which in legalistic terms meant he had never taken pos- session of the land. These enemies of Columbus issued capitulaciones (contracts) allowing others to explore what Columbus had discovered. Thus, at least two voyages to the Paria Peninsula were undertaken in 1499 , one by Alonso de Hojeda (or Ojeda) and the other by Peralonso (or Pedro Alonso) Niño. Besides cutting valuable brazilwood (Caesalpina echinata) (Defilipps 1998), these explorers obtained $44.16 \mathrm{~kg}$ of pearls through trade (Sauer 1966). The richest pearl oyster beds were east of Cubagua and Coche, east and southeast of Margarita, and northwest of the Araya Peninsula (Fig. 2). From 1500 on, this section of the coastline was known as the Costa de las Perlas (Pearls' Coast) (Morón 1954). An expedition led by Luis Guerra in 1502 yielded a costal (sackfull, approximately $46 \mathrm{~kg}$ ) of pearls (Mosk 1938). Because the Spanish Crown had declared the pearl trade a royal monopoly, it is possible that many more Spaniards from the mainland, Hispaniola, or Borinquen (Puerto Rico) ventured illegally into Cubagua during those years, leaving no historical record of their exploitation or their impact on the pearl oyster beds.

\section{First European Settlements (1502-1508)}

Unauthorized travelers established the first European settlements in Cubagua, which consisted of clay and straw huts (rancberías). These rancherías were occupied for 3-4 months each year during trading (Rouse \& Cruxent 1963). In 1504, given the increasing demand for pearls and the potential tax benefits to the Spanish Crown, King Ferdinand ordered his governor at Hispaniola, Nicolás de Ovando, to build a fortress on the Costa de las Perlas to provide protection and a base for pearl commerce. The next year Ovando organized an expedition to scout for the best place for the fortress and to establish commercial relations with the natives. Ovando returned to Spain with 39 marks (approximately $9 \mathrm{~kg}$ ) of pearls. In 1509 Ovando wrote a report to the king in which he recommended not building a city on Cubagua because of the lack of freshwater. He further explained that having developed good relationships with the natives, there was no need for further conquests because trade could continue for many years. He also recommended that visits to Cubagua be prohibited to those who extracted pearls without paying taxes. These recommendations were never implemented (Sauer 1966).

In its early stages, trade went well. Apparently the Spaniards tried to maintain good relations with the Guayquerí Indians (the local Arawaks) of Margarita in order to avoid the mistakes made in Hispaniola, where the Spaniards alienated and eradicated the local labor force. Natives were happy to trade pearls for wine, linen shirts, wheat bread, firearms, and other European goods. Friendly settlers were given a native woman as a wife or concubine, and the Spaniards made themselves valuable as protectors against the Carib attacks and the incur- 
sions of other Spaniards from the mainland who sought to enslave the Guayquerís.

However, tensions soon arose. As more Spaniards poured into these islands, the natives started to demand more for the pearls and insisted that the Europeans go to Margarita Island to haggle for them. Further, because the Guayquerís were more than satisfied with the initial level of trade, they showed little interest in intensifying pearl extraction. This irritated the growing number of Spaniards who became convinced that the only means of satisfying their demand for pearls was to enslave the natives. Any native who resisted Spanish sovereignty or who was labeled a "cannibal" could be legally enslaved (Hulme 1986).

\section{Large-Scalle Exploitation (1508-1520)}

The increasing demand for pearls led to the introduction of enslaved natives from many other Caribbean islands and coastal areas of Venezuela (Willis 1976). As early as 1508, large numbers of Lucayan Indians from the Bahamas were taken by force to Cubagua (Watts 1987). Lucayan Indians were especially prized for their swimming and deep-diving abilities, skills they had developed through the aboriginal practice of diving for conchs (Strombus spp.). The Lucayans could dive $30 \mathrm{~m}$ or more, and the average pearl bed was at about $13 \mathrm{~m}$ and the deepest at about 22 m (Mosk 1938). By 1518 the Bahamas had been completely depopulated of Lucayans from a population believed to be originally 60,000 (Muilenburg 1991). Africans were also imported and taken to Cubagua to toil in the pearl fisheries (Galtsoff 1950).

All contemporary accounts describe the treatment of the native pearl divers as harsh. Divers worked from dawn to dusk, six per boat. They dove to the pearl oyster beds attached to a rope that was tugged after a minute or so. The rope was used to quicken the time for the divers to surface. Each diver was equipped with a small pouch fastened to his waist or neck. There he placed oysters as he collected them from the bottom. If diving in deeper waters, the diver weighed himself down with two heavy stones in order to reach the bottom faster and remain there longer while spending less energy. Divers were allowed little rest time between dives, and if they delayed too long, the overseer whipped them. In 1 or 2 weeks one of these boats would harvest some 35,000 oysters. At night the pearl divers were chained so they could not escape. Most divers died from either hemorrhages caused by decompression or shark attacks (Oviedo Y Valdez 1535; de Las Casas 1552/1992; von Humboldt 1799-1804/1956; Morón 1954; Helmer 1962).

From 1509 on, the Spanish authorities tried to stimulate the establishment of permanent settlements in $\mathrm{Cu}-$ bagua. The Spanish government opened up the pearl trade by reducing the tax from $50 \%$ to $20 \%$ of gross pro- duction, but the lack of water, wood, and construction materials prevented the Spanish from establishing longterm residency on the island. In 1512, the Spanish attempted to encourage a permanent settlement by asking the Dominican friars to settle off the coast of Cumaná (or the nearby Chichirivichi or Píritu), where the Manzanares River could provide fresh water to the colonists in Cubagua. This failed because of the revenge the natives took on the friars as a consequence of their mistreatment by other Spaniards. In 1516, trade with natives in wine and firearms for pearls was prohibited because of increasing native hostility (Otte 1961).

In 1519 Charles V became King of Spain. An increased demand for luxury in the court intensified the demand for pearls. By that time, with a resident population of nearly 300, Nueva Cádiz had become a true "frontier town," plagued by administrative corruption, drinking, gambling, murder, adultery, and the rape of native women. These excesses led, in 1520 , to a major rebellion by the natives. The Spaniards responded a year later with a punitive expedition that decimated many of the native groups of the region (Simon Velásquez 1956; Otte 1961; Muilenburg 1991).

\section{Rise and Fall of Nueva Cádiz (1523-1545)}

The Spaniards did not control the Pearls' Coast politically and militarily until they built a fortress at Cumaná in 1523. This brought the continental natives under control and allowed Cubagua to reach its economic splendor. The Spaniards brought stones to the island from the Araya peninsula and erected permanent brick buildings. They also constructed public buildings and masonry houses. The Franciscan monastery was probably the most impressive of these buildings. It displayed elaborately carved stone gargoyles imported either from the South American mainland or Spain (Rouse \& Cruxent 1963). The city of Nueva Cádiz was incorporated in 1527, becoming the first European city in South America. It had a population of 223 Europeans and 700 natives. Between 1530 and 1535 fisheries were being exploited to the maximum and supported a total population of between 1000 and 1500 (Morón 1954; Otte 1961).

In 1528 the Spanish king authorized an associate to dredge the pearl oyster beds from which the king would receive one-third of the profits. The citizens of Nueva Cádiz complained before His Majesty because they believed this practice would severely deplete the oyster beds. As a result of these complaints the use of dredges was authorized only beyond 6 fathoms (approximately $10 \mathrm{~m}$ ). The first signs of exhaustion of the pearl oysters occurred at this time (Fig. 3).

By 1531 the city had 1000 inhabitants, and depletion in the pearl oyster beds became more acute (Morón 1954). In what may have been the first case of conserva- 


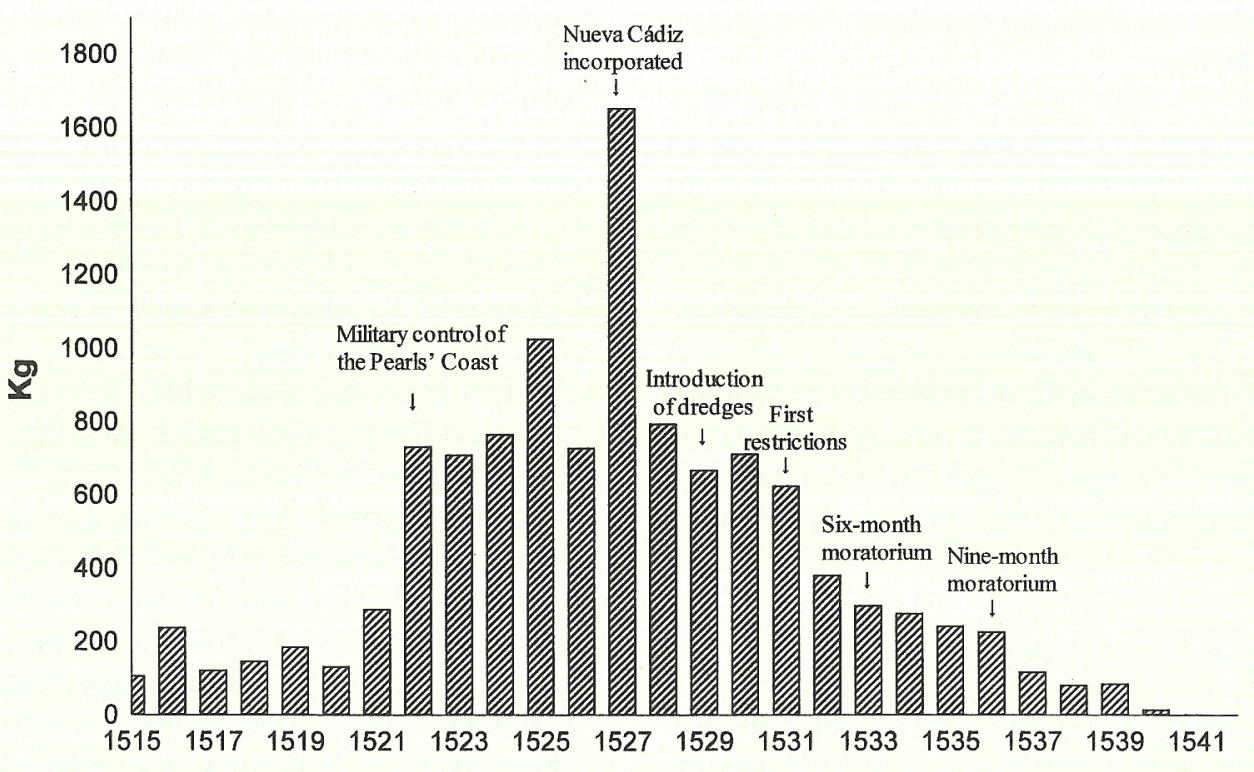

Year

Figure 3. Pearl production in kilograms based on tax information from 1515, when tax records became available, until 1542, when production fell to zero. Historical events are consistent with oyster exploitation and pearl production. For example, large-scale production did not start until the Spaniards gained full control of the pearl oyster bed areas; the city of Nueva Cádiz was incorporated at the beight of pearl production; the introduction of dredges helped maintain production for 2 or 3 years (after which depletion of the beds became acute); restrictions and moratoriums were never effective, probably because they were too little too late.

tion measures recorded in modern history, the Spaniards limited both boat size and the number of divers per boat. They also limited pearl diving to 4 hours per day at depths not to exceed $13 \mathrm{~m}$. These restrictions, however, were applied only to certain beds. There is no evidence that these new rules were enforced (Galtsoff 1950 Helmer 1962).

In 1533 the Spaniards established a 6-month moratorium. From 1535 on the divers found the oysters only at great depths. That year Cubagua began to be depopulated in favor of newly discovered pearl oyster beds on the South American coast, such as Cabo de La Vela and Rio Hacha off the Guajira Peninsula (Fig. 1; Luengo Muñoz 1949). In 1536 further depletion led the Spaniards to extend the moratorium on pearl fishing in Cubagua from January to September (Otte 1977). The next year the Crown learned that no pearls had been obtained in a year and a half. This, together with attacks by pirates, resulted in the accumulation of debt on the island. The Spanish could no longer successfully finance the colony (Helmer 1962). By 1537 only one pearl fisher per boat was allowed, and in 1539 there were only between 10 and 50 people left on the island. In 1541 a hurricane-like storm (Vila 1948) destroyed the remaining buildings. This was followed in 1543 by an attack by French corsairs that forced the remaining Spaniards to leave for Margarita. Therefore, in only 45 years, from Co- lumbus's first trade to the abandonment of the colony, the pearl oyster beds had been completely depleted. Later attempts to recolonize Cubagua failed (Quiévreux 1900; Mosk 1938; Goggin 1968; Willis 1976). By the 1960 s, $96 \%$ of the pearl oyster banks were completely or almost completely depleted and the pearl oysters had been replaced by the turkey-wing mussel (Salaya \& Salazar 1972).

\section{Economic Background}

Although many of the pearls harvested were sent back to Spain and used in clothes and jewelry for the nobility and ornamentation for the church, most of them were traded to other nations for manufactured goods. The Spanish relied so heavily on pearls as a trade medium that they were left with a broken economy once the supply from the Americas was depleted (Helmer 1962). Because Spain had traded its new wealth (including gold) to other countries, it was left with practically no long-term benefit from the pearls and gold into which it had invested so much time and effort.

The Spanish on Cubagua used the great output of pearls to live a luxurious lifestyle that they maintained even after the yield of pearls diminished (Helmer 1962). Lack of local resources and rapid, extraordinary wealth 
encouraged price inflation of essential goods. Prices for products in Cubagua were about those for goods in Santo Domingo (Otte 1977), which resulted in an insurmountable debt (Willis 1976).

The economy of Cubagua was unsustainable. The island lacked essential natural resources. Water, wood, diversified sources of food, construction material, and other necessities all had to be imported (Rouse \& Cruxent 1963). Local food sources included oysters, turtles, fish, wild mammals such as deer (probably captured in Margarita Island) and rabbits (probably from both Margarita and Cubagua), and marine birds from Margarita and the mainland. A few remains of domesticated animals such as pigs, chickens, sheep, goats, and cows have been found. These animals were probably slaughtered immediately after being brought to the island because the lack of natural vegetation in Cubagua did not provide appropriate conditions for grazing animals. Some cats and dogs were also introduced (Wing 1961). Pigs and chickens were a bit more common, probably because they are less dependent on natural vegetation to survive and can be fed with human refuse (Reitz 1991, 1992). The vegetables eaten at that time included the manioc and the cassava, both brought from elsewhere in the Caribbean.

A few pearls can still be obtained in the Cubaguan waters from natural extraction, yet the development of cultured pearls in the early twentieth century (Matsui 1975) rendered such extraction economically nonviable.

\section{Social and Political Impacts of the Pearl Oyster Exploitation}

In addition to its role as a pearl production center, Nueva Cádiz served two other functions: it was a collection point for slaving activities on the mainland and a jumping-off spot for the first Spanish attempts at colonizing the South American mainland. The expansion of agricultural practices in the Caribbean, coupled with the rapid extermination of most of the native population of the larger islands by colonists, resulted in high demand for slaves at correspondingly high prices. Nueva Cádiz's location made it a perfect spot to collect captured natives from the mainland to be shipped to buyers in the Greater Antilles. Further, to gain access to pearl oyster beds, a person had to be a Señor de Canoa (boat lord), a title of legal stature that was achieved by owning at least 12 pearl divers. In 1535 some Señores de Canoa may have had up to 50 divers, and the wealthiest in the island had more than one boat (Otte 1977).

The proportion of Europeans to non-Europeans (mostly Native Americans, but also Africans) may have been 1:4 or $1: 5$ by the height of pearl exploitation (Rouse \& Cruxent 1963). Because of the high mortality among slave divers, the high demand for cheap slave labor and women, and the low human population density along the Venezuelan coast (approximately 50,000 at the time of Columbus's arrival; Lockhart \& Schwartz 1983), the local indigenous population was rapidly decimated. There was a great deal of translocation of people, the most significant example being the Lucayans.

\section{Impact of Exploitation on Pearl Oyster Population Ecology}

Based on tax records (summarized in Otte 1961), I estimated that the total weight of pearls produced from Cubagua between 1515 and 1542 was, at a minimum, $11,326 \mathrm{~kg}$. One kilo equals 50 carats, so total gross production was 566,300 carats. We do not know the actual productivity of Cubagua's pearl oysters. The most conservative calculation of pearl productivity is $200-300$ oysters per carat ( $0.20 \mathrm{~g}$ ) (Galtsoff 1950 ). Taking the most conservative approximation of 200 oysters per carat, this means that, at a minimum, 566,300 carats of production were the result of harvesting $113,260,000$ oysters. Although I have not been able to find any estimate of the natural population size of this species in any location that would put this number in context, this figure is astonishing, especially if one considers the conservative nature of the estimate. The total number of oysters harvested could be reasonably multiplied by at least a factor of two if one assumes, as contemporary accounts indicate, that less than half of the actual production was declared. Also, it is important to remember that for these calculations I used figures only from those years for which there are tax records and ignored extraction in those years (1498-1514) for which tax records were not kept. Further, historical records (Otte 1961) indicate that, in actuality, only one pearl was produced for every 1000 oysters collected. This would allow us to further multiply my estimations by five. In other words, it is reasonable that many more than one billion oysters were extracted in $<30$ years.

To see whether human labor could sustain such production, I used figures for the year of 1527 , in which exploitation reached its highest level. In that year the production was of 7170 marks $(1,649.1$ kilos, 82,455 carats) of gross production. Using Galtsoff's (1950) conservative production estimates and following the protocol described in the Methods section, we can estimate that at least 16,491,000 oysters were harvested that year. The total human population in Cubagua for 1527 has been estimated at 223 Europeans and 700 natives (Otte 1961). Assuming that Europeans were not involved in the actual diving for pearls and that of the 700 local natives only 500 were involved in diving for pearls, each one of them would have harvested 32,982 oysters that year. Assuming that these divers were not made to work on Sundays, they worked 313 days per year. Thus, on average, they collected 105 pearls per day. We know natives were made to work from dawn to dusk (i.e., at least 12 hours of labor per day), that each dive lasted about 1 minute (Helmer 1962), and that each diver's pouch 
could contain several dozen oysters. Assuming, conservatively, that they collected 12 oysters per dive (easy to collect because they tend to clump together in groups of 6-12) and worked only 10 hours a day, the divers would have made about nine dives per hour per day to reach the above figures. Therefore, these calculations are conservative. Further, Rouse and Cruxent (1963) estimated that the Nueva Cádiz population reached a maximum of 1500 residents. This figure suggests that there were more than 1000 natives and Africans on the island, making my calculations even more credible, especially because I did not take into account the oysters that were obtained with dredges.

One factor that may have furthered the virtual extinction of the pearl oyster beds around Cubagua was that the local species has a relatively low pearl productivity and small size. For example, about $10 \%$ of the individuals of Pinctada galtsoffi of Hawaii contain pearls (Galtsoff 1933), whereas from the contemporary accounts it could be inferred that productivity was $1 \%$ or less of oysters containing pearls. Also, Cubagua's pearls seem to have been rather small in size compared with those from the Indian and Pacific oceans (Kunz \& Stevenson 1908 ). Most of them were of 2, 3, 4, and 5 carats (Benzoni 1565). Thus, to make this enterprise yield an amount comparable to that achieved in other parts of the world, the Spaniards had to make an additional extractive effort.

Although the biology of Pinctada imbricata Röding 1798 (Pteriidae), is not fully understood (Gervis \& Sims 1992), contemporary accounts and my own calculations can help us infer the causes for depletion. For example, we know that one of the reasons the Spaniards brought Lucayans into Cubagua was their ability to dive deeper than other indigenous people. As shallower oyster beds became depleted and divers had to go deeper to obtain pearls, depth complicated production. Results of recent studies suggest that abundance and growth rates diminish beyond $8 \mathrm{~m}$ in depth (Verginelli \& Prieto 1991). That means that once the oysters found at their optimal depth had been depleted, pearl production had to decrease exponentially regardless of the fishing effort.

Why did Pinctada imbricata fail to recover despite establishment of quotas and moratoriums at the time of exploitation and long after all attempts of exploitation ceased? The answer may involve a combination of two factors: reproductive cycle and competition.

Maximum recruitment for this species occurs in March and the minimum in July. Moratoriums established by the Spanish took place ad hoc. Because they had no knowledge of the biology of this species, those moratoriums were ineffective. Also, the life span of this species is only 5 years, and pearls are not produced until individuals reach 4 years of age (Verginelli \& Prieto 1991). Spaniards harvested as many oysters as they could, including those that were immature, because divers at that time did not use goggles, which would make the distinction between, say, a 2-year-old oyster and a 4-year-old one virtually impossible, and because divers who surfaced with an empty basket were whipped.

Today, most of what used to be the pearl oyster beds have been replaced by beds of the turkey-wing mussels (Arca zebra). P. imbricata and A. zebra are sympatric in many areas of the Caribbean, practice suspensionfeeding, and are often exposed to the same food resources and environmental conditions. Both species are epifaunal, attaching by bysii to hard substrata in the rocky and shallow sandy shores of sounds, bays, harbors, and lagoons. A. zebra, however, may have a competitive advantage over $P$. imbricata.

Because the method of intense exploitation practiced by the Spaniards likely generated resuspension of bottom sediments, this could have greatly increased the concentration of suspended particulate matter (SPM) and altered the composition of the seston (suspended particles). In many cases, resuspended inorganic materials reduce the quality of the seston by diluting food particles that are suspended in the water column, such as phytoplankton and particulate organic material (Ward \& MacDonald 1996). With high levels of SPM, A. zebra preferentially ingests material that lowers the ratio of carbon to nitrogen and enhances the quality of material ingested by an average of $31 \%$. Thus, they physiologically compensate for a decrease in food quality.

As a result of different gifl structures, $A$. zebra has lower feeding rates than $P$. imbricata and different mechanisms for particle rejection and pseudofeces production (Ward \& MacDonald 1996). In other words, under conditions of ecological stress generated by overexploitation of $P$. imbricata and a higher concentration of SPM, A. zebra would have been better suited to outcompete $P$. imbricata. By occupying substratum previously covered with $P$. imbricata, $A$. zebra would have prevented the effective recovery of the pearl oysters. This is a likely scenario given that (1) several surveys made in Cubagua and adjacent waters in the $1960 \mathrm{~s}$ showed that almost all the $P$. imbricata banks in the region were completely or almost completely decimated; (2) A. zebra has ecologically replaced $P$. imbricata (Salaya \& Salazar 1972); and (3) there is no evidence that A. zebra was exploited in significant numbers by the Spaniards (it does not produce pearls). This pattern of depletion of pearl oyster banks by overexploitation has been documented elsewhere in the world (Galtsoff 1932; Cariño Olvera 1995; Jackson et al. 2001).

\section{Conclusions}

The combination of historical accounts, tax data, and current knowledge of the biology of the species involved provides a reasonable picture of the process lead- 
ing to the depletion or even extinction of a species or population. Historical accounts and tax information are consistent with each other in explaining the way in which the pearl oyster beds became depleted (Fig. 3). Although there is no way to test specific hypotheses because these events took place when scientific information was nonexistent, such consistency may be the best way to interpret the facts. This approach may be the only one that can allow us to understand the dynamics of the depletion of the pearl oyster beds. After all, historical data can be used to clarify underlying causes and rates of ecological change and to provide useful information for restoration ecology and management of coastal ecosystems that cannot be derived from recent observations alone (e.g., Jackson et al. 2001).

The depletion of pearl oyster beds at Cubagua is also interesting because it exemplifies a pattern of unsustainable development and illustrates a failed attempt at conservation at a time when there was no science to back up conservation measures. It represents not only the first but also what would prove a persistent example of overutilization of natural resources in the post-Columbian Americas. Case studies like this are even more interesting when one considers that ecological extinction caused by overexploitation precedes all other pervasive human disturbance in coastal areas (Jackson et al. 2001). Therefore, the study of extinction through examination of historical records is essential to our understanding of the ecological history of a particular area. Similar results based on tax information can be obtained by analyzing the exploitation of marine mammals by coastal fishers in the Caribbean (Romero et al. 1997, 2002; Romero \& Hayford 2000).

My study demonstrates that exploitation based on the determination to obtain maximum wealth as rapidly as possible leads to the depletion of the resource itself and to serious human rights abuses for the benefit of certain social elites. Sadly, Cubagua's example is not unique, and overexploitation of pearl oyster beds leading to political, economic, and ecological turmoil has been documented in varying degrees elsewhere (e.g., Tuamotu Archipelago in French Polynesia [Rapaport 1995]; Scotland [Green 1985-1986]; India and Sri Lanka [de Silva 1978]). But because the colonial powers found well-structured societies in those parts of the world, their impact was not as great as that of the Spaniards on the Pearls' Coast. The demand for slaves in pearl-fishing operations has had a significant social impact throughout history. As late as the nineteenth century, slaves were taken from Africa by Islamic slave traders for pearl fishing in the Red Sea (Austen 1988). In their narratives, historical ecologists tend to consider humans as part of nature. The case of the Cubaguan pearl oysters represents an extreme example because of its effects on the human populations involved, including those of Africans who were forcibly brought to work in the pearl-fishing industry.
Further studies that transcend standard academic barriers and look at environmental problems from an integrative and interdisciplinary viewpoint will generate new insights in resource management and appreciation of the human dimensions of many of the environmental problems we face today. The combination of tax records and historical and ecological information I present offers one good example of such interdisciplinary research. This approach in historical ecology (e.g., Balee 1998) should produce new and better understanding of the relationship between humans and the environment. This, in turn, may initiate changes in the way conservation biologists are trained today. Interdisciplinary approaches must be used to illuminate the human dimensions of ecological problems (Jacobson \& McDuff 1998).

\section{Acknowledgments}

T. Martinez-Verne read an early version of the manuscript and made valuable suggestions. P. Southgate provided valuable information on oyster biology. S. Chilbert and M. G. Eisenhart located documentation and commented on an earlier version of the manuscript. G. K. Meffe, C. Meine, and two anonymous reviewers provided useful comments.

\section{Literature Cited}

Agenbroad, L. D., J. I. Mead, and L. W. Nelson. 1990. Megafauna and man: discovery of America's heartland. The Mammoth Site of Hot Springs, Hot Springs, South Dakota.

Alvard, M. S. 1995. Intraspecific prey choice by Amazonian hunters. Current Anthropology 36:789-818.

Anonymous. 1970. Léxico estratigráfico de Venezuela. Boletín de Geología, Publicación Especial 4:1-756.

Austen, R. A. 1988. The 19th century Islamic slave trade from East Africa (Swahili and Red Sea Coasts): a tentative census. Slavery \& Abolition 9:21-44.

Balee, W., editor. 1998. Advances in historical ecology. Columbia University Press, New York.

Benzoni, G. 1565. La historia del Mondo Nuovo. Appresso Francesco Rampazetto, Venetia.

Bernabeu, S. 1995. Perlas para la Reina. Aportaciones al estudio de la industria perlífera en la Nueva España (1790-1809). Estudios de Historia Novohispana 15:129-158.

Buege, D. J. 1996. The ecologically noble savage revisited. Environmental Ethics 18:71-88.

Cariño Olvera, M. M. 1995. La pesca y el cultivo de perlas en la region de La Paz (1870-1940): su impacto socioeconómico. Siglo XIX: Cuadernos de Historia 2:27-48.

Carlton, J. T. 1993. Neoextinctions of marine invertebrates. American Zoologist 33:499-509.

Coates, P. 1998. Nature: Western attitudes since ancient times. University of California Press, Berkeley.

Cooke, R. 1998. Human settlement of Central America and northernmost South America (14,000-8,000 BP). Quaternary International 49(50):177-190.

Crumley, C., editor. 1994. Historical ecology: cultural knowledge and changing landscapes. School of American Research Press, Santa Fe, New Mexico. 
de Castellanos, J. 1589/1847. Elegías de varones ilustres de Indias. M. Rivadeneyra, Madrid.

de Las Casas, B. 1552/1992. The devastation of the Indies: a brief account. The Johns Hopkins University Press, Baltimore, Maryland:

de Silva, C. R. 1978. The Portuguese and pearl fishing off South India and Sri Lanka. South Asia 1:14-28.

Defilipps, R. A. 1998. Historical connections between the discovery of Brazil and the Neotropical brazilwood, Caesalpina echinata Lam. Archives of Natural History 25:103-108.

Diamond, J. 1998. Guns, germs, and steel: the fates of human societies. Norton, New York.

Egan, D. and E. A. Howell, editors. 2001. The historical ecology handbook: a restorationist's guide to reference systems. Island Press, Washington, D.C.

Forester, D. J., and G. E. Machlis. 1996. Modeling human factors that affect the loss of biodiversity. Conservation Biology 10:1253-1263.

Galtsoff, P. S. 1932. The coral reefs of the Hawaiian islands. The Collecting Net 7:29-30.

Galtsoff, P. S. 1933. Pearl and Hermes Reef, Hawaii, hydrographical and biological observations. Bernice P. Bishop Museum Bulletin 107:3-49.

Galtsoff, P. S. 1950. The pearl fishery of Venezuela. Fisheries, Special Scientific Report:26:1-26.

Gervis, M. H., and N. A. Sims. 1992. The biology and culture of pearl oysters (Bivalvia: Pteriidae). Overseas Development Administration, London.

Goggin, J. M. 1968. Spanish majolica in the New World: types of the sixteenth to eighteenth centuries. Department of Anthropology, Yale University, New Haven, Connecticut.

Green, M. 1985-1986. The history of Scotland's freshwater pearls. British Heritage 7:28-35.

Haring, C. H. 1964. Trade and navigation between Spain and the Indies. Peter Smith, Gloucester, United Kingdom.

Headland, T. N. 1997. Revisionism in ecological anthropology. Current Anthropology 38:605-630.

Helmer, M. 1962. Cubagua, l'ile des perles. Annales 17:751-760.

Henige, D. P. 1998. Numbers from nowhere: the American Indian contact population debate. University of Oklahoma Press, Norman.

Hulme, P. 1986. Colonial encounters: Europe and the native Caribbean, 1492-1797. Methuen, London.

Jackson, J. B. C. 2001. What was natural in the coastal oceans? Proceedings of the National Academy of Sciences of the United States of America 98:5411-5418.

Jackson, J. B. C., et al. 2001. Historical overfishing and the recent collapse of coastal ecosystems. Science 293:629-638.

Jacobson, S. K., and M. D. McDuff. 1998. Training idiot savants: the lack of human dimensions in conservation biology. Conservation Biology 12:263-267.

Johnston, J. R. 1909. Flora of the Islands of Margarita and Coche, Venezuela. Contributions from the Grey Herbarium of Harvard University. New Series. 37:163-312.

Kallendorf, H. 1995. A myth rejected: the noble savage in Dominican Dystopia. Journal of Latin American Studies 27:449-470.

Kugler, H. G. 1957. Contribution to the geology of the islands Margarita and Cubagua, Venezuela. Bulletin of the Geological Society of America. 68:555-566.

Kunz, G. F., and C. H. Stevenson. 1908. The book of the pearl. Century, New York.

Lockhart, J., and S. B. Schwartz. 1983. Early Latin America. A history of colonial Spanish America and Brazil. Cambridge University Press, Cambridge.

López de Gómara, F. 1554/1965. Historia general de las Indias. Editorial Iberia, Barcelona.

Luengo Muñoz, M. 1949. Noticias sobre la fundación de la Ciudad de Nuestra Señora Santa María de los Remedios, del Cabo de la Vela. Anuario de Estudios Americanos 6:755-798.

Martin, P. S. 1973. The discovery of America. Science 179:969-974.
Martin, P. S. 1990 . 40,000 years of extinctions on the "planet of doom." Palaeogeography, Palaeoclimatology, Palaeoecology 82: 187-201.

Martin, P. S., and C. R. Szuter. 1999. War zones and game sinks in Lewis and Clark's West. Conservation Biology 13:36-45

Matsui, Y. 1975. On the origin of pearl-culture and the history of it in Japan. Proceedings of the 14th International Congress of the History of Science 3:39-42.

McCann, J. M. 1999a. Before 1492: the making of the pre-Columbian landscape. I. The environment. Ecological Restoration 17:15-30.

McCann, J. M. 1999b. Before 1492: The making of the pre-Columbian landscape. II. The vegetation, and implications for restoration for 2000 and beyond. Environment. Ecological Restoration 17:3-15.

Meine, C. 1999. It's about time: conservation biology and history. Conservation Biology 13:1-3

Morón, G. 1954. Los orígenes históricos de Venezuela. I. Introducción al Siglo XVI. Consejo Superior de Investigaciones Científicas, Madrid.

Mosk, S. A. 1938. Spanish pearl-fishing operations on the Pearl Coast in the sixteenth century. The Hispanic American Historical Society Review 18:392-400.

Muilenburg, P. 1991. Fate and fortune on the Pearl Coast. Américas 43: 32-39.

Olivo Chacín, B. 1989. Geografia de la región insular del mar venezolano. Ariel-Seix Barral Venezolana, Caracas.

Otte, E. 1961. Cedulario de la monarquía española relativo a la Isla de Cubagua (1523-1550), Tomo I (1523-1534) y Tomo II (15351550). Fundación John Boulton y Fundación Eugenio Mendoza, Caracas.

Otte, E. 1977. Las perlas del Caribe: Nueva Cádiz de Cubagua. Fundación John Boulton, Caracas.

Oviedo Y Valdez, G. F. 1535. Historia natural y general de las Indias. Juan Cromberger, Madrid.

Pastor Bodmer, B. 1992. The armature of conquest:.Spanish accounts of the discovery of America, 1492-1589. Stanford University Press, Stanford, California.

Pimm, S. L. 1996. Lessons from a kill. Biodiversity Conservation 5: 1059-1067.

Ponting, C. 1991. A green history of the world: the environment and the collapse of great Civilizations. Penguin Books, New York.

Quiévreux, H. 1900. La pêche des perles au Venezuela. La Revue Maritime 146:444-448.

Rapaport, M. 1995. Oysterlust: islanders, entrepreneurs, and colonial policy over Tuamotu lagoons. Journal of Pacific History 30:39-52.

Reitz, E. J. 1991. Dieta y alimentación Hispano-Americana en el Caribe y la Florida en el siglo XVI. Revista de Indias 51:11-24.

Reitz, E. J. 1992. The Spanish colonial experience and domestic animals. Historical Archaeology 26:84-91.

Romero, A., and K. Hayford. 2000. Past and present utilization of marine mammals in Grenada. Journal of Cetacean Research and Management 2:223-226.

Romero, A., I. Agudo, and S. Green. 1997. Exploitation of cetaceans in Venezuela. Reports of the International Whaling Commission 47: 735-746.

Romero, A., A. Singh, A. McKie, M. Manna, R. Baker, and J. E. Creswell. 2002. Environmental history of marine mammal exploitation in Trinidad and Tobago: W.I. and its ecological impact. Environment and History 8:255-274.

Rouse, I. 1964. Prehistory of the West Indies. Science 144:499-513

Rouse, I., and J. M. Cruxent. 1963. Venezuelan archaeology. Yale University Press, New Haven, Connecticut.

Salaya, J. J., and L. Salazar. 1972. Exploraciones y explotaciones de la ostra perla (Pinctada imbricata) en Venezuela, 1946-1969. Proyecto de Investigación y Desarrollo Pesquero Ministerio de Agricultura y Cría, Programa de las Naciones Unidas para el Desarrollo, and Food and Agriculture Organization, Caracas. 
Sale, K. 1991. The conquest of paradise: Christopher Columbus and the Columbian legacy. Alfred A. Knopf, New York.

Sauer, C. O. 1966. The early Spanish Main. University of California Press, Berkeley.

Simmons, I. G. 1993. Environmental history: a concise introduction. Blackwell Science, Oxford, United Kingdom.

Simon, J. 1997. Prophecy, plague, and plunder. The Amicus Journal 997:28-33.

Simon Velásquez, J. 1956. Petróleo y perlas en Cubagua. Revista Shell 5:45-52.

Verginelli, R., and A. Prieto. 1991. Producción secundaria de Pinctada imbricata (Röding, 1798) (Pterioida: Pteriidae) en una población del Golfo de Cariaco, Venezuela. Acta Científica Venezolana 42: 138-144.

Vila, P. 1948. La destrucción de Nueva Cádiz \&iquest;terremoto o huracán? Boletín de la Academia Nacional de la Historia 31:213219.

von Humboldt, A. 1799-1804/1956. Viaje a las regiones equinoc-

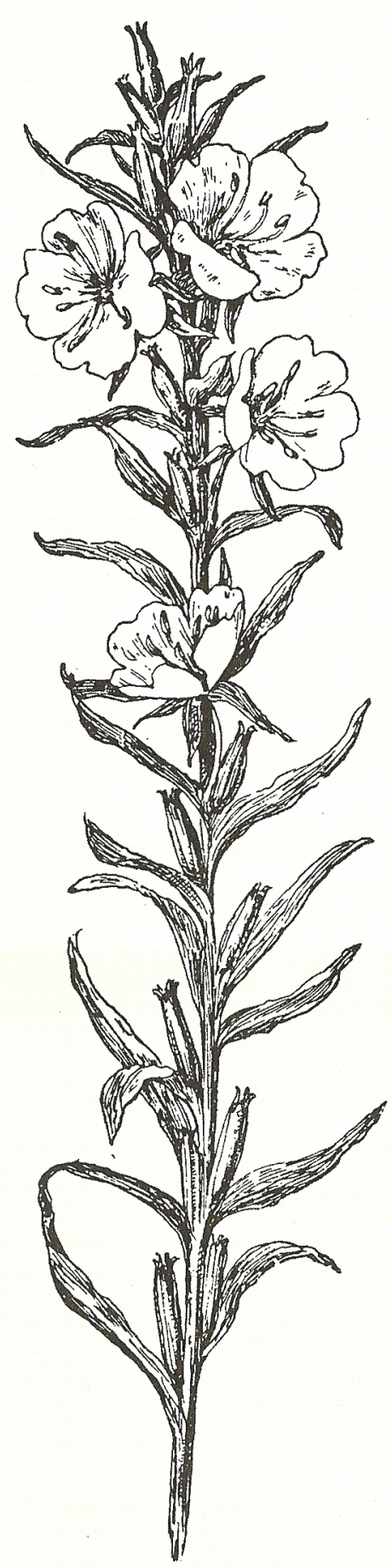

ciales del Nuevo Continente. 5 volumes. Ministerio de Educación, Caracas.

Ward, J. E., and B. A. MacDonald. 1996. Pre-ingestive feeding behaviors of two sub-tropical bivalves (Pinctada imbricata and Arca zebra): responses to an acute increase in suspended sediment concentration. Bulletin of Marine Science 59:417-432.

Watts, D. 1987. The West Indies: patterns of development, culture and environmental change since 1492. Cambridge University Press, Cambridge, United Kingdom.

Webster, D., and G. Webster. 1984. Optimal hunting and Pleistocene extinction. Human Ecology 12:275-289.

Willey, G. R. 1971. An introduction to American archaeology. 2. South America. Prentice-Hall, Englewood Cliffs, New Jersey.

Willis, R. F. 1976. The archeology of 16th century Nueva Cadiz. M.A. thesis. University of Florida, Gainesville.

Wing, E. S. 1961. Animal remains excavated at the Spanish site of Nueva Cadiz on Cubagua Island of Venezuela. Niewe West-Indische Gids $41: 162-165$.

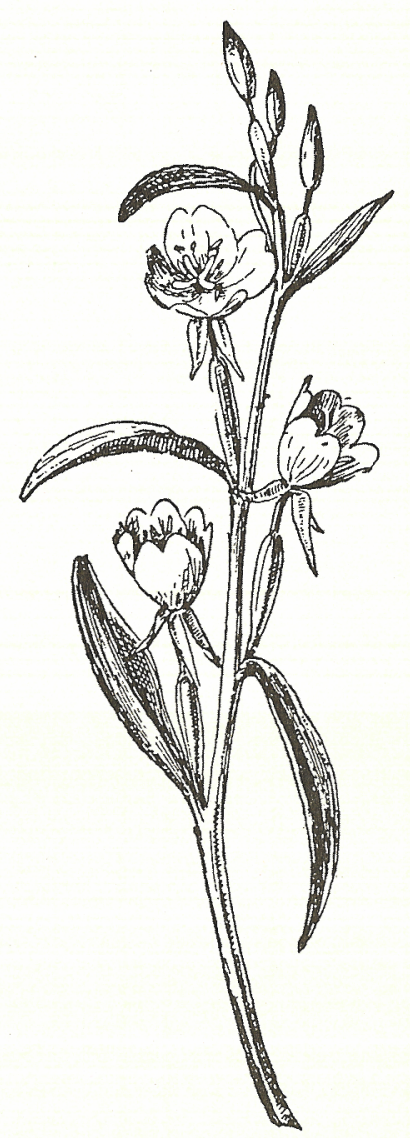

